\title{
Collation Article
}

\section{Assessment and Comparison of Commonly Used Eutrophication Indexes}

\section{Yaygın olarak Kullanılan Ötrofikasyon Indekslerinin Değerlendirilmesi ve Karşılaştırılması}

\author{
Duygu Ülker, İrşad Bayırhan, Selmin Burak \\ Istanbul University, Institute of Marine Sciences and Management, Department of Marine \\ Environment, 34116 Fatih, Istanbul \\ duygu.ulker@istanbul.edu.tr (https://orcid.org/0000-0002-6279-7321),ibayirhan@istanbul.edu. \\ tr (https://orcid.org/0000-0001-9404-399X), sburak@istanbul.edu.tr (https://orcid.org/0000-0003- \\ 0780-0687)
}

Received Date: 28.06.2019, Accepted Date: 27.11.2019

\begin{abstract}
Eutrophication is a phenomenon that causes the degradation of water quality which results in negative impacts on living and non-living environment of any water body. Therefore, monitoring, evaluation and classification of water quality are the utmost important issue for policy makers and regional institutions/organizations in order to assess the quality and sustainable use of water bodies and to take appropriate measures. Regional conventions such as the Helsinki Convention, Oslo-Paris Convention, Barcelona Convention - Programme for the Assessment and Control of Marine Pollution in the Mediterranean, Strategic Action Programme and Integrated Coastal Zone Management as well as legislative instruments such as the Water Framework Directive, Marine Strategy Framework Directive, Urban Wastewater Treatment Directive and Nitrates Directive in Europe; the Clean Water Act, Water Quality Act, National Environmental Policy and Coastal Zone Management Act issued by the United States Environmental Protection Agency addresses the importance of monitoring for eutrophication. The eutrophication indexes have been developed in line with regional requirements using specific data sets of state variables and parameters, representative of a location. In this study, we reviewed commonly used eutrophication indexes within the areas applied, parameters, methods and classification scales and presented the trophic status equivalences between the indexes. This study aimed to provide a comprehensive examination of eutrophication indexes to researchers in trophic status assessment of any water body.
\end{abstract}

Keywords: Trophic status classification, eutrophication indexes, water quality management

\section{Öz}

Ötrofikasyon su kütlesindeki canlı ve cansız çevre üzerinde olumsuz etkilere yol açarak su kalitesinde bozulmalara sebep olan bir olgudur. Bu nedenle, su kalitesinin izlenmesi ve sinıflandirılması, su kütlelerinin kalitesini ve sürdürülebilir kullanımını değerlendirebilmek ve gerektiğinde rehabilitasyonu için zamanında ve yerinde önlemler alabilmek adına politika yapıcılar ve bölgesel kurumlar/kuruluşlar için büyük önem taşımaktadır. Bölgesel sözleşmelerden Helsinki Sözleşmesi, Oslo-Paris Sözleşmesi, 
Barselona Sözleşmesi - Akdeniz'de Deniz Kirliliğinin Değerlendirilmesi ve Kontrolü Programı, Stratejik Eylem Programı ve Entegre Kıyı Alanları Yönetimi ve yasal araçlardan Su Çerçeve Direktifi, Deniz Stratejisi Çerçeve Direktifi, Kentsel Atıksu Arıtımı Direktifi ve Nitrat Direktifi; Amerika Birleşik Devletleri Çevre Koruma Ajansı tarafindan yayınlanan Temiz Su Yasası, Su Kalitesi Yasası, Ulusal Çevre Politikası ve Kıyı Bölgesi Yönetim Yasası, ötrofikasyonu önlemek adına izlemenin önemine değinir. Bölgesel gereklilikler doğrultusunda ötrofikasyon indeksleri, bir bölgeyi temsil eden belirli durum değişkenleri ve parametrelerden oluşan veri setleri kullanılarak geliştirilmiştir. Bu çalışmada, dünya çapında yaygın olarak kullanılan ötrofikasyon indeksleri uygulama alanları, parametreleri, yöntemleri ve sınıflandırma ölçeklerine göre incelenmiş ve indekslerin trofik durum eşdeğerleri ortaya konmuştur. Bu çalışma, bir su kütlesinin trofik durum değerlendirmesinde araştırmacılara ötrofikasyon indeksleri ile ilgili kapsamlı bir inceleme sunmak amacıyla yapılmıştır.

Anahtar kelimeler: Trofik durum sinıflandırma, ötrofikasyon indeksleri, su kalitesi yönetimi

\section{Introduction}

In ecosystems, living and non-living environment interacts each other(Kupchella \& Hyland, 1989). For example, algal growth relies on nutrient uptake whose main mechanism enables the removal of dissolved nutrient from water. Algae constitutes the boosting compounds for primary production in lakes and estuaries, having a prevailing role in subsequent trophic status (Bowie et al., 1985). Eutrophication occurs under the effect of algal dynamics and poses significant problems to aquatic ecosystem as losses in biodiversity, ecosystem degradation, harmful algal blooms (HAB) and oxygen deficiency in bottom waters (EC 2010/477/EU, 2010; EU 2008/56/EC, 2008).

Eutrophication is one of the most important threats for ecological health and water quality (Dodds, 2002; HELCOM, 2007; Jiang et al., 2011; OSPAR, 2008; Pan et al., 2015). Despite the nutrients are natural ingredients of the ecosystem, their excessive concentrations may cause negative effects in the aquatic strata (Heiskary \& Bouchard Jr, 2015). Dramatic increase of nitrogen and phosphorus accelerates algal growth and thus, biomass increases. Harmful algal species altered by the eutrophication dominate other algae populations. Changing the balance between organisms results in the degradation of water quality (Heiskary \& Bouchard Jr, 2015). Overgrowth of algae and later, inhibition of sun rays in water surface causes the shading decay, suffocation and even toxicity in shellfishes and fishes. In that sense, the effects of nutrient enrichment are increase in chlorophyll concentration, decrease in water transparency related to suspended algae, abundance of opportunistic macro algae, abundance of perennial seaweeds and seagrasses, decrease in dissolved oxygen, species shift in floristic composition (EC 2010/477/EU, 2010). 
Three types of HAB occur in aquatic ecosystem related with the global increase of nutrient pollution which are toxic algae, potentially toxic algae, and red tides. Toxic algae mainly involve Karenia, Alexandrium, Dinophysis and Pseudonitzschia whereas potentially toxic algae mainly refer to Pseudonitzschia. The occurrence of red tides is generated by large biomass blooms which may compose of Phaeocystis, Lepidodinium, Noctiluca, and reflect brownish, green or white tides (Ferreira et al., 2011; USEPA, 2008). Some of the studies shows HAB occurrence in aquatic ecosystem in Turkey. For example, Tas and Noyan (2015) listed 23 potentially harmful and/or bloom-forming microalgae of the Golden Horn Estuary which includes species of Pseudonitzschia, Dinophysis, Noctiluca. Turkoglu (2013) observed that dramatically increase on density of Noctiluca scintillans in bloom period March-June and OctoberDecember in Çanakkale Strait.

There are significant causes of nutrient enrichment in water resources namely population increase resulting in domestic wastewater discharges and overuse of nitrogen and phosphorus in agriculture. As a result of these pressures, aquatic ecosystem continues to alter the sources in the food chain (Galloway \& Cowling, 2002; Glibert et al., 2006; Howarth et al., 2002; Smil, 2004).

In the light of the above-mentioned reasons, the appropriate amount of nutrients to protect the aquatic life, and the relationship between the biological conditions of aquatic organisms and the nutrient concentrations requires a variety of methods to describe. Considering chronological studies on eutrophication assessment, the studies of Hoyer et al. (2015) and Kitsiou and Karydis (2011) have gained the importance. The focus of relevant scientific resources is mainly on aquatic ecosystem's health and therefore, nutrient concentrations in water. The prominent studies about eutrophication indexes were the ones related mainly to phosphorus concentrations (Canfield Jr \& Bachmann, 1981; Chapra, 1977; Liebig, 1840; Vollenweider, 1976). Thereafter, estimation of chlorophyll concentrations from total phosphorus was studied (Canfield Jr \& Bachmann, 1981; Jones \& Bachmann, 1976). The chlorophyll concentration might still be regarded as an important indicator independently. On the other hand, studies on water clarity were carried out and trophic status was defined by the level of dependent phytoplankton colonization (Carlson, 1977; Hoyer et al., 2015; USEPA, 2008). In that sense, various models were developed in order to assess the relationship between biodiversity and nutrient loads (Cloern, 2001). Finally, various indexes were developed to determine the trophic status based on specific indicators (e.g. dissolved oxygen (DO), dissolved inorganic nitrogen (DIN), dissolved inorganic phosphorus (DIP), total nitrogen (TN), total phosphorus (TP), secchi disk depth (SD), chlorophyll-a (Chl-a), seagrass, macrobenthos, HAB, benthic invertebrates, 
phytoplankton, primary production, phanerogam coverage $(\mathrm{Ph})$ ) (Bricker et al., 2003; Bricker et al., 1999; Carlson, 1977; Cloern, 2001; Giordani et al. 2009; HELCOM, 2007; Ignatiades, 2005; Souchu et al., 2000; USEPA, 2008; Vollenweider et al., 1992; EC WFD, 2009). These parameters and biological indicators are commonly used in research and management of lakes and coastal waters (Andersen et al., 2011; Conley et al., 2000; Cunha et al., 2013; Devlin et al., 2011; Nielsen et al. 2002; Parparov et al., 2010; Pettine et al., 2007; Rask et al., 1999; Rinaldi \& Giovanardi, 2011; Stips et al., 2016).

The indexes provide statistical data on water quality for research and management activities according to the sustainability criteria and objectives of local or regional conventions and legislative frameworks (e.g. to achieve good ecological status (GES) by Water Framework Directive (WFD), to achieve successful goals by United State Environmental Protection Agency (USEPA), to protect the Northeast Atlantic by Oslo-Paris Convention (OSPAR), to protect Baltic Sea by Helsinki Convention (HELCOM), to protect the Mediterranean Sea by the Programme for the Assessment and Control of Marine Pollution in the Mediterranean (MEDPOL)) (HELCOM, 2007; OSPAR, 2008; USEPA, 2008; EC, 2000).

In this study, worldwide used eutrophication indexes evaluated and compared with regard to their parameters, variables, regions and specific states.

\section{Method}

\section{Commonly Used Eutrophication Indexes}

Several eutrophication monitoring and assessment methods have been developed and implemented in lakes and marine water bodies. The summary of these methods based on their integrated indicators and implementation areas (Table 1). 
Table 1

Methods for eutrophication assessment modified from Ferreira et al. (2011) and Borja et al. (2012)

\begin{tabular}{|c|c|c|c|c|}
\hline Method name & $\begin{array}{l}\text { Area of } \\
\text { application }\end{array}$ & $\begin{array}{l}\text { Biological } \\
\text { indicators and } \\
\text { parameters }\end{array}$ & $\begin{array}{l}\text { Physico- } \\
\text { chemical } \\
\text { parameters }\end{array}$ & Assessment \\
\hline $\begin{array}{l}\text { EPA NCA } \\
\text { Water Quality } \\
\text { Index }\end{array}$ & US & Chl-a & $\begin{array}{l}\text { Water clarity, } \\
\text { DO, DIN, DIP }\end{array}$ & Classified as good, fair, poor \\
\hline TRIX & EU & Chl-a & DO, DIN, TP & $\begin{array}{l}\text { Scales from } 0 \text { (elevated) to } 10 \\
\text { (bad). }\end{array}$ \\
\hline ASSETS & $\begin{array}{l}\text { US, EU, } \\
\text { Asia, } \\
\text { Australlia }\end{array}$ & $\begin{array}{l}\text { Chl-a, macroalgae, } \\
\text { seagrass, HAB }\end{array}$ & DO & $\begin{array}{l}\text { Scales from high to bad in four } \\
\text { categories }\end{array}$ \\
\hline TWQI/LWQI & EU & $\begin{array}{l}\text { Chl-a, macroalgae, } \\
\text { seagrass, phanerogam } \\
\text { coverage }(\mathrm{Ph})\end{array}$ & DO, DIN, DIP & $\begin{array}{l}\text { Scales from } 0 \text { (worst status) to } \\
100 \text { (best status). }\end{array}$ \\
\hline OSPAR & $\begin{array}{l}\text { North East } \\
\text { Atlantic }\end{array}$ & $\begin{array}{l}\text { Chl-a, macroalge, } \\
\text { seagrass, } \\
\text { phytoplankton } \\
\text { indicator species }\end{array}$ & $\begin{array}{l}\text { DO, TP, TN, } \\
\text { DIN, DIP }\end{array}$ & $\begin{array}{l}\text { Identify non-problem areas, } \\
\text { potential problem areas and } \\
\text { problem areas }\end{array}$ \\
\hline WFD & $\begin{array}{l}\text { Basque } \\
\text { Country, UK }\end{array}$ & $\begin{array}{l}\text { Phytoplankton, } \\
\text { Chl-a, macroalgae, } \\
\text { benthic invertebrates, } \\
\text { seagrass }\end{array}$ & $\begin{array}{l}\text { DO, TP, TN, } \\
\text { DIN, DIP, } \\
\text { water clarity }\end{array}$ & $\begin{array}{l}\text { Scales from high to bad in five } \\
\text { categories }\end{array}$ \\
\hline HEAT & Baltic & $\begin{array}{l}\text { Chl-a, primary } \\
\text { production, seagrass, } \\
\text { benthic invertebrates, } \\
\text { HAB, macroalgae }\end{array}$ & $\begin{array}{l}\text { DIN, DIP, TN, } \\
\text { TP, DO, water } \\
\text { clarity }\end{array}$ & $\begin{array}{l}\text { Areas with values }<1.00 \text { are } \\
\text { defined as 'unaffected by } \\
\text { eutrophication', while areas with } \\
\text { values } \geq 1.00 \text { are defined } \\
\text { impaired and 'affected by } \\
\text { eutrophication'. }\end{array}$ \\
\hline BEAST & $\begin{array}{l}\text { Black Sea, } \\
\text { Ukraine } \\
\text { Romania, } \\
\text { Bulgaria }\end{array}$ & $\begin{array}{l}\text { Chl-a, primary } \\
\text { production, seagrass, } \\
\text { benthic invertebrates, } \\
\text { HAB, macroalgae }\end{array}$ & $\begin{array}{l}\text { DIN, DIP, TN, } \\
\text { TP, DO, water } \\
\text { clarity }\end{array}$ & Scales from 1 (high) to 5 (bad) \\
\hline IFREMER & France & $\begin{array}{l}\text { Chl-a, seagrass, } \\
\text { macrobenthos, HAB }\end{array}$ & $\begin{array}{l}\text { DO, water } \\
\text { clarity, SRP, } \\
\text { TP, TN, DIN, } \\
\text { DIP, sediment } \\
\text { organic matter, } \\
\text { sediment }\end{array}$ & $\begin{array}{l}\text { Scales from blue (high) to } \\
\text { red(bad) in five categories }\end{array}$ \\
\hline CTSI & $\begin{array}{l}\text { North } \\
\text { America }\end{array}$ & Chl-a & TP, SD & $\begin{array}{l}\text { Oligotrophic CTSI } \leq 40 \\
\text { Mesotrophic } 40<\text { CTSI } \leq 50 \\
\text { Eutrophic } 50<\text { CTSI } \leq 70 \\
\text { Hyper-eutrophic CTSI }>70\end{array}$ \\
\hline TLI (for lakes) & & Chl-a & $\mathrm{SD}, \mathrm{TP}, \mathrm{TN}$ & $\begin{array}{l}\text { Scales from } 1 \text { (ultramicrotrophic) } \\
\text { to } 7 \text { (hypertrophic) }\end{array}$ \\
\hline
\end{tabular}




\section{Environmental Protection Agency National Coastal Assessment (EPA NCA) Water Quality Index (WQI).}

This index has been used to characterize degraded water quality conditions in the US waters. The criteria have been identified for East/Gulf Coast Sites, West Coast, Hawaii, Puerto Rico and Florida Bay. According to the EPA 2004 report, water quality cannot be described by a simple index for all estuarine systems. For instance, an index cannot work out for a specific estuary while it may be used for several regions appropriately. Therefore, it is important to determine which indicator should be weighted greater or less according to the characteristics of the region.

EPA, NCA and WQI includes five parameters which are Chl-a, water clarity, DO, DIN and DIP. It describes poor, fair and good water quality status for each parameters and defines a WQI value according to the number of each parameters specific to region (see Table 2 and Table 3) (USEPA, 2004)

Table 2

Regional Biological Parameter Criteria (USEPA, 2004)

\begin{tabular}{lccc}
\hline & \multicolumn{3}{c}{ Chl-a $\left(\mu \mathrm{g} \mathrm{L}^{-1}\right)$} \\
\hline Good & Fair & Poor \\
Hawaii, Puerto Rico & $<5$ & $5-20$ & $>20$ \\
Florida Bay & $<0.5$ & $0.5-1$ & $>1$ \\
\hline
\end{tabular}

Table 3

Regional Physico-chemical Indicator Criteria (USEPA, 2004)

\begin{tabular}{lcccccccccccc}
\hline & \multicolumn{3}{c}{ DIN $\left(\mathrm{mg} \mathrm{L}^{-1}\right)$} & \multicolumn{3}{c}{ DIP $\left(\mathrm{mg} \mathrm{L}^{-1}\right)$} & & \multicolumn{3}{c}{ WCI ratio* } & & \multicolumn{3}{c}{ DO $\left(\mathrm{mg} \mathrm{L}^{-1}\right)$} \\
\hline & Good & Fair & Poor & Good & Fair & Poor & Good & Fair & Poor & Good & Fair & Poor \\
\hline $\begin{array}{l}\text { East/Gulf Coast } \\
\text { Sites }\end{array}$ & $<0.1$ & $0.1-0.5$ & $>0.5$ & $<0.01$ & $0.01-0.05$ & $>0.05$ & & & & & & \\
& & & & & & & & & & & & \\
West Coast sites & $<0.5$ & $0.5-1.0$ & $>1$ & $<0.01$ & $0.01-0.1$ & $>0.1$ & & & & & & \\
Hawaii, Puerto \\
$\begin{array}{l}\text { Rico, Florida } \\
\text { Bay }\end{array}$
\end{tabular}


Criteria for the determination of the WQI specific to region are given as "good status: maximum one parameter is fair, and none of parameters are poor"; "fair status: one of the parameters is poor or two/more parameters are fair"; "poor status: two/more of the five parameters are poor" (USEPA, 2004).

\section{Trophic Index (TRIX).}

As a multimetric index, TRIX describes trophic status regarding four indicators (Chl-a, DO, DIN, DIP). It was presented by Vollenweider within the scope of the OECD Programme on Eutrophication (Vollenweider \& Kerekes, 1980; Vollenweider et al., 1998). This index was formed to evaluate the coastal water quality in Italy by collecting data between 1982-1993 along the coast of Emilia-Romagna in NW Adriatic. The area was strongly affected by the Po river inputs (Vollenweider et al., 1992).

TRIX was adopted by MEDPOL for trophic classification of the coastal waters in Mediterranean Sea and by this way, the parameters of TRIX were agreed to be monitored (UNEP/MAP, 2007a, 2007b; WFD 2000/60/EC Technical Report, 2009). TRIX was also used in various areas of the Mediterranean Sea (e.g. Adriatic Sea and Tyrrhenian Sea) (EC WFD Technical Report, 2009).

Four parameters of TRIX are Chl-a, oxygen as absolute (\%) deviation from saturation, DIN (as $\mathrm{NO}_{3}-\mathrm{N}+\mathrm{NO}_{2}-\mathrm{N}+\mathrm{NH}_{4}-\mathrm{N}$ ) and $\mathrm{TP}$ (Giovanardi \& Vollenweider, 2004; R. Vollenweider et al., 1998). Numerically, the index scales from 0 to 10 covering a wide range of trophic conditions from oligotrophy to eutrophy. Accordingly, lower TRIX values show a good eutrophication status, while higher values represent worse conditions.

The basic structure of TRIX is given below Eq. 1 and Eq. 2:

$$
\operatorname{TRIX}=(k / n) \sum_{1}^{i=n}\left(\frac{\log U-\log L}{\log M-\log L}\right) i
$$

where

$\mathrm{k}$ : scale coefficient,

$\mathrm{n}$ : number of the variables,

i: number of the variables,

M: measured value of the variable,

U: upper limit,

L: lower limit. 
TRIX $=(\log 10[\mathrm{ChA} \times \mathrm{aD} \% \mathrm{O} \times \operatorname{minN} \times \mathrm{TP}]-\mathrm{k}) / \mathrm{m}$.

where

ChA: chlorophyll- $a$ concentration $\left(\mu \mathrm{g} \mathrm{L}^{-1}\right)$,

$\mathrm{aD} \% \mathrm{O}$ : oxygen as absolute \% deviation from saturation,

minN: mineral nitrogen: DIN: $\mathrm{N}\left(\right.$ as $\left.\mathrm{NO}_{3}-\mathrm{N}+\mathrm{NO}_{2}-\mathrm{N}+\mathrm{NH}_{4}-\mathrm{N}\right)\left(\mu \mathrm{g} \mathrm{L}^{-1}\right)$,

TP: total phosphorus $\left(\mu \mathrm{g} \mathrm{L^{-1 }}\right)$

$\mathrm{m}$ : scale coefficient

In addition to TRIX, turbidity index (TRBIX) defines the Secchi disc (SD) transparency in combination with chl-a concentration. The trophic index (TRIX) is combined with turbidity index (TRBIX) and a general water quality index (GWQI) is formed covering microbiological conditions (Vollenweider et al., 1998).

TRIX is studied also in Mediterranean, Aegean Sea, Marmara Sea and Black Sea between the years of 2014-2017 by Ministry of Environment and Urbanization of Turkey (MEU) (MEU, 2018). For instance, their results show that in the Mediterranean, minnimum TRIX value is less than 1 and maximum is more than 5 and in the Marmara Sea, minnimum TRIX value is less than 3 and maximum is more than 6 .

\section{Assessment of Estuarine Trophic Status (ASSETS).}

A substantial part of ASSETS methodology was developed for National Estuarine Eutrophication Assessment (NEEA) by Bricker et al. (1999). NEEA has three tools as Overall Eutrophic Condition (OEC), Overall Human Influence (OHI) and Definition of Future Outlook (DFO). This approach combines primary and secondary symptoms. NEEA approach was extended by Bricker et al. (2003) as ASSETS method by modelling the relative contribution of anthropogenic nutrient sources (OHI) and based on the combination of relational databases (e.g., Geographical Information Systems) with a more quantitative procedure (e.g., statistical criteria) for the determination of parameters to evaluate the status of OEC (Bricker et al., 2003).

While NEEA is applied only in the coastal waters of United States, ASSETS aims to cover the requirements of the WFD with regard to a few quality elements for transitional waters (S. Bricker et al., 2003). ASSETS which is a synthesis of three different NEEA tools: OEC, OHI and DFO, defines five categories as bad, poor, moderate, good and high, respectively. The categories of $\mathrm{OHI}$ value are classificated as low: 0 to $<0.2$, moderate low: $>0.2$ to 0.4 , moderate: $>0.4$ to 0.6 , moderate high: $>0.6$ to 0.8 and high: $>0.8$, respectively. 
The OEC value has two groups that are primary (early) and secondary (advanced) symptoms of eutrophication. Chl-a, macroalgae and epiphytes are considered primary symptoms. Low DO, losses of submerged aquatic vegetation (SAV) and occurrence of nuisance and/or toxic algal blooms are considered secondary symptoms.

The formulas indicating symptom level and the level of expression value for primary symptoms obtained are given below (Bricker et al., 2003).

$$
\begin{aligned}
& \sum_{i=1}^{n}\left(\frac{A z}{A e}\right)(\text { Expression Value })=\text { Sypmtom level of expression value for estuary } \\
& P 1=\frac{1}{p} \sum_{1}^{P}\left[\sum_{1}^{n}\left(\frac{A z}{A e} E 1\right)\right]
\end{aligned}
$$

where

$\mathrm{Az}$ is the surface area of each zone,

Ae is the total estuarine surface area,

$\mathrm{E}_{1}$ is the expression value at each zone,

$\mathrm{n}$ is the number of estuarine zones,

$\mathrm{P}_{1}$ is the level of expression of the primary symptoms for the estuary,

$\mathrm{p}$ is the number of primary symptoms (Bricker et al., 2003).

Evaluation of ASSETS method is based firstly on the selection of the highest of the three estuary symptom level of expression values, secondly on the chosen the level of expression value of secondary symptoms for the estuary. Secondary symptoms are evaluated to be a clear indicator of the problem. The evaluation is done based on expression values between $0-1$ and the conditions as high, moderate high, moderate, moderate low and low, respectively (Bricker et al., 2003).

According to the ASSETS approach, some primary symptoms (e.g. epiphytes) and secondary symptoms (e.g. toxic blooms) may only be evaluated by estimation while others such as Chl-a and DO contents are assessed based on the quantitative values (Bricker et al., 2003).

\section{Transitional Water Quality Index (TWQI).}

TWQI was developed from the water quality index of the U.S. National Sanitation Foundation by Giordani et al. (2009). It is a simple tool which integrates the information from abiotic and biotic measurements where SAV controls primary 
production due to shallow depth and provides a comprehensive assessment of trophic status quantitatively. This multimetric index includes six main variables which are the relative coverage of benthic phanerogams and opportunistic macroalgae species, concentrations of DO, phytoplankton, Chl-a, DIN and DIP (Giordani et al., 2009). The index scales from 0 (worst status) to 100 (best status).

TWQI has been used in transitional waters of Southern Europe. TWQI is obtained by the sum of weighted Quality Values as a non-linear quality function of measured variables as described in Eq. 5 (Bonometto et al., 2016).

$$
\text { TWQI }=\sum(w f Q V s)
$$

Where wf is weighing factors and QVs is the quality values of the six main variables.

\section{Oslo Paris Convention Method (OSPAR).}

The OSPAR Common Procedure inserts two procedural stages: an initial screening of the selected marine areas and the implementation of a comprehensive procedure assessment. Screening stage identifies the areas where there is no eutrophication threat. These areas are classified as "non-problem area" which does not need second stage of comprehensive procedure assessment. The other classifications fall under "potential problem area" and "problem area" which need to apply comprehensive procedure assessment (OSPAR, 2008).

The OSPAR comprehensive procedure has four categories to evaluate eutrophication conditions in North East Atlantic. Category 1, namely nutrient enrichment, includes nutrient inputs, DIN and DIP concentrations in winter period. Category 2, namely direct effects of nutrient enrichment, includes Chl-a concentration, elevated levels of toxic phytoplankton indicator species and macrophytes and shift from long-lived to short-lived nuisance macrophytes species. Category 3, namely indirect effects of nutrient enrichment, includes oxygen deficiency, kills and long-term area-specific changes in zoobenthos biomass and fish and elevated levels of organic carbon/organic matter (area-specific) in relation to oxygen deficiency. Category 4, namely other possible effects of nutrient enrichment, includes algal toxins and transboundary transport. 


\section{Water Framework Directive (WFD).}

The WFD has five ecological classes which are "high, good, moderate, poor and bad", aimed to achieve good ecological status in all European water bodies by 2015 (EC, 2000; WFD Guidance, 2003). However, a large number of exemptions were given to member states for extending the first deadline (2015) for meeting the objectives to further deadlines as 2021 or 2027 due to technical inability, disproportionate expenses or natural barriers for timely improvement (Tsakiris, 2015). Each member state is required to adapt the WFD assessment processes. In this context, eutrophication assessment is done to define ecological status where nutrient enrichment changes biological and physico-chemical parameters.

The WFD has two assessments. The first one is ecological status assessment for current situation and reveals eutrophication status indicating the movement of quality elements towards moderate/poor/bad. The second is risk assessment (predictive analysis) to estimate future condition and prevent deterioration using information on predicted changes in pressure that likely end in aquatic environment under the risk of eutrophication in near future (EC WFD Technical Report, 2009).

Marine Strategy Framework Directive (MSFD) as a sub-directive of WFD aims to achieve "Good Environmental Status (GES)" in the marine environment by 2020 at the latest, while the WFD aims "Good Ecological Status". MSFD focuses on minimizing anthropogenic sources of eutrophication in marine environment, while the WFD covers the whole pressures for eutrophication. MSFD has complementarity with the WFD in coastal waters as defined in Article 3.1 of MSFD (EC WFD Technical Report, 2009)

\section{HELCOM Eutrophication Assessment Tool (HEAT) and Black Sea Eutrophication Assessment Tool (BEAST).}

HEAT is an eutrophication indicator and developed for the Baltic Sea where eutrophication has been a major problem since the 1900s (HELCOM, 2007). Based on the same principles already proposed by Vollenweider (1998) HEAT determines eutrophication level by five parameters which are nitrogen, phosphorus, chl-a, water clarity and oxygen.

HEAT identifies areas as "affected by eutrophication" and "unaffected by eutrophication" according to the Ecological Quality Ratio (EQR). EQR changes between 0 (worst) and 1 (best). The threshold value of EQR is 0,67 and if the result is less than 0,67 , it is unacceptable as its deviations from reference conditions are 
moderate, major or strong indicating that the area affected by eutrophication as its status is moderate, poor or bad (HELCOM, 2009).

BEAST is developed for the Black Sea within the scope of the EU funded Baltic2Black Project and tested for the eutrophication assessment of the Romanian coastal waters (BSC, Helcom \& EC, 2014). It has the same principles with HEAT and its parameters are specific to country (Lazar et al., 2016). According to the developer of the HEAT tool, BEAST could ideally be an improved version of HEAT. It can also be used to assess the influence of seawater temperature at eutrophic condition (BSC, Helcom \& EC, 2014)

\section{Institut Français pour l’Exploration de la Mer (IFREMER).}

IFREMER is in charge of the overall coordination of the WFD in France. IFREMER method uses mean annual or mean seasonal data compared to a fixed scale to define the status for chl-a with five coloured level to match the WFD evaluation (see Table 4). The IFREMER method is based on the description of physical, chemical and biological potential indicators of eutrophication in the various sections of the lagoon ecosystem: benthic, phytoplankton, macrophytes, macrofauna, sediment and water. This method uses the $90^{\text {th }}$ percentile of annual or seasonal Chl-a data (Souchu et al., 2000; Zaldívar et al., 2008).

Table 4

Trophic Status Classification Based on IFREMER (Zaldivar et al., 2008)

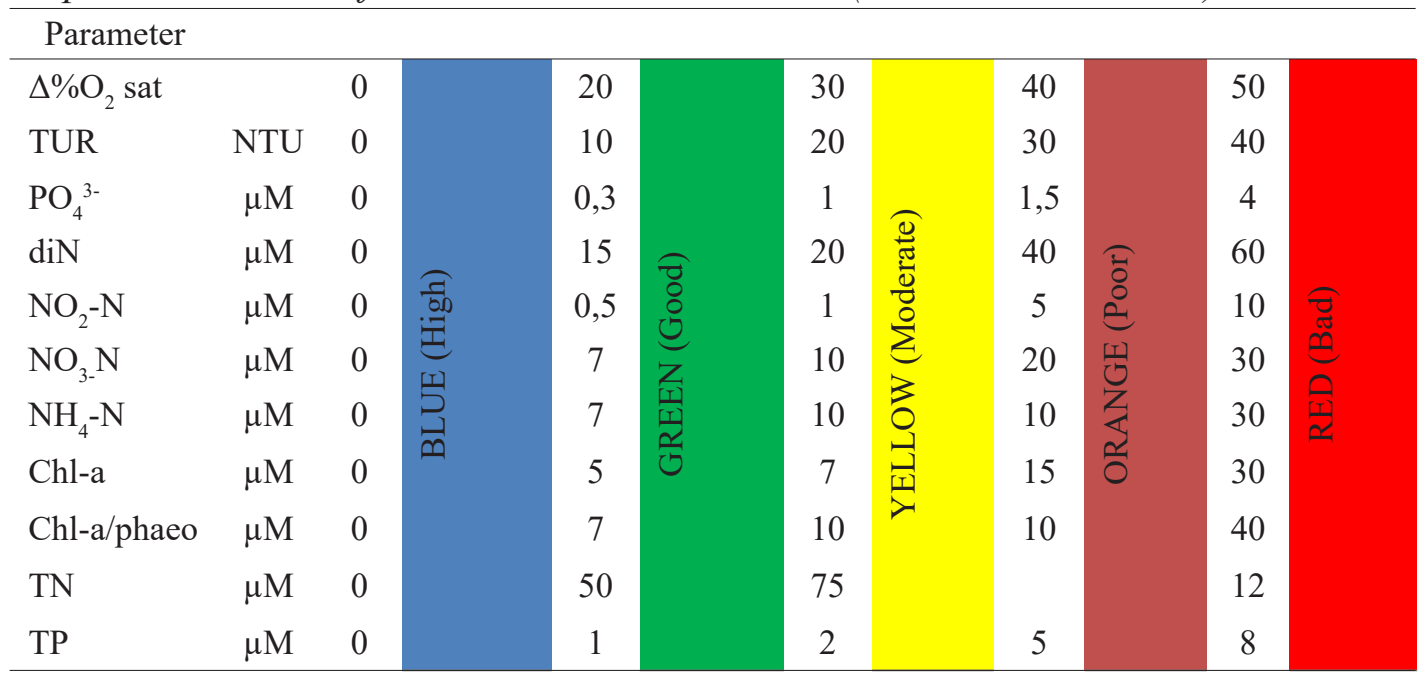




\section{Statistical Trophic Index (STI).}

STI method was implemented in the Aegean Sea by Ignatiades (2005). This index defines the classification as "open oligotrophic $<$ offshore mesotrophic $<$ inshore eutrophic waters" according to Chl-a content and primary production. Accordingly, the values for index parameters are $0.5<(0.5-1.0)<1.0 \mathrm{mg} \mathrm{m}^{-3}$ and $1.5<(1.5-3.0)<3.0$ $\mathrm{mg} \mathrm{C} \mathrm{m} \mathrm{m}^{-3} \mathrm{~h}^{-1}$ for Chl-a and primary production, respectively (Ignatiades, 2005).

\section{Carlson Trophic State Index (CTSI).}

CTSI was calculated in three Minnesota Lakes in 1972. This index used SD transparency, TP and Chl-a as indicator parameters. According to Carlson, the best indicator of trophic status may differ from one lake to another and seasonally. For this reason, the best indicator should be chosen pragmatically (Carlson, 1977).

Carlson derived the TSI formula using the equations of the relationship between TP and summer Chl-a concentration defined by Dillon and Rigler (1974). CTSI is calculated via the formulas below (Carlson, 1977).

$$
\begin{aligned}
& \text { TSI } S D=10 \quad 6-\frac{\ln S D}{\ln 2} \\
& \text { TSI } C \bowtie l=106-\frac{2,04-0,68 \ln C \otimes l}{\ln 2} \\
& \text { TSI TP }=106-\frac{\ln \frac{48}{T P}}{\ln 2} \\
& \text { CTSI }=\frac{1}{3} \text { TSI SD + TSI C凶l+TSI(TP) }
\end{aligned}
$$

where

TSI is trophic state index,

SD is secchi disk,

Chl-a is surface chlorophyll-a concentration $\left(\mathrm{mg} / \mathrm{m}^{3}\right)$,

TP is total surface phosphorus concentration $\left(\mathrm{mg} / \mathrm{m}^{3}\right)$

The index indicates the potential concentration of a watershed or region, at least on the basis of phosphorus. Table 5 gives the classification of CTSI. 
Table 5

\begin{tabular}{ll} 
Trophic StatusClassification According to & CTSI (Carlson \& Simpson, 1996) \\
\hline Trophic State & CTSI value \\
\hline Oligotrophic & $\leq 40$ \\
Mesotrophic & $40<\mathrm{CTSI} \leq 50$ \\
Eutrophic & $50<\mathrm{CTSI} \leq 70$ \\
Hypertrophic & $\mathrm{CTSI}>70$ \\
\hline
\end{tabular}

\section{Trophic Level Index (TLI).}

TLI has been used for lakes in New Zealand. The index includes three indicators which are SD depth, TP and Chl-a concentrations. TLI has subsequently been supported with TN concentrations. Thus, each individual index of TLI (Tli) is the form of a logarithmic function connecting the trophic level to four "trophic" parameters (Burns et al., 2000).

$$
\mathrm{Tli}=\mathrm{ai}+\mathrm{biLOG}(\text { Pari })
$$

where

I shows the indices (each of the four parameters), $a$ and $b$ are coefficients, $\mathrm{Par}_{\mathrm{i}}$ is SD depth, concentration of TN, TP and Chl-a

Equations (11), (12), (13) and (14) given below for the indices of TLI were defined with the coefficients by Burns et al. (1999) and Burns et al. (2000).

$$
\begin{aligned}
& \text { TLc }=2.22+2.54 \log (\text { Chl-a }) \\
& \text { TLs }=5.10+2.27 \log (1 / \mathrm{SD}--1 / 40) \\
& \text { TLp }=0.218+2.92 \log (\mathrm{TP}) \\
& \text { TLn }=-3.61+3.01 \log (\mathrm{TN})
\end{aligned}
$$

Calculation of TLI is as below Eq. (15).

$$
\mathrm{TLI}=1 / 44\left(\mathrm{TL}_{\mathrm{Chl}}+\mathrm{TL}_{\mathrm{SD}}+\mathrm{TL}_{\mathrm{TP}}+\mathrm{TL}_{\mathrm{TN}}\right)
$$

TLI has seven classification categories ranking from 1 (ultramicrotrophic) to 7 (hypertrophic). 


\section{Assessment of Eutrophication Indexes}

Throughout the development stages of eutrophication indexes, information about trophic status has been provided to local authorities and policy makers. International legislation like the WFD and the USEPA require further developing tools, which can be implemented for different water bodies. Therefore, integrated approaches for combining, analysing and evaluating information from various interrelated variables are important for water quality management, environmental sustainability and development of cost-effective indicators regarding eutrophication. Consequently, different targets are required for water bodies at regional scale.

The indexes show that trophic status of water bodies related with nutrient levels, water clarity (Secchi disc depth), DO and Chl-a levels, and the phytoplankton community regarding physical, chemical and biological aspects. Additionally, it is observed that the main phytoplanktonic parameter Chl-a is a common parameter for all eutrophication indexes as it is directly related to the trophic status.

On the other hand, there is not any internationally defined and accepted eutrophication index. Indexes are developed using specific data sets of state variables and parameters representing a location. Therefore, there is not comparability between indexes as they are specific to the region where they have been developed. They might be adopted by the additional data representing the study area.

It is observed that the requirements of USEPA and WFD for eutrophication monitoring are taken as basic approach. The EPA method is associated with US waters, while the WFD comprises water resources of the European Union and candidate countries. The WFD addresses all types of pressures and hence, assessment is done accordingly. However, the HEAT and OSPAR indexes take into account nutrient enrichment and deriving impacts.

In order to calculate an EQR, deviation from the recent monitoring data and the data related to type-specific reference conditions are compared as recommended by the WFD and HEAT. The results are assessed based on the status of the quality element having the worst condition (one-out all-out principle).

The OSPAR uses area-specific and/or historical reference levels for each criteria. This method reflects an additive mechanism across causative, direct and indirect effects as well as other tangible effects. According to the WFD Guidance No 23, the OSPAR Common Procedure can be tested by non-OSPAR Contracting Parties 
but it is a difficult to handle nutrients as it only uses winter values of nutrients and is used in open seas (WFD 2000/60/EC Technical Report, 2009).

Table 6

Comparison of Assessment Results According to WFD Guidance No 23 (EC WFD Technical Report, 2009)

\begin{tabular}{|c|c|c|c|c|}
\hline $\begin{array}{l}\text { Ecological } \\
\text { status }\end{array}$ & WFD & OSPAR & HELCOM & MSFD \\
\hline High & $\begin{array}{l}\text { Nearly undisturbed } \\
\text { conditions }\end{array}$ & $\begin{array}{l}\text { Non- } \\
\text { problem } \\
\text { area }\end{array}$ & $\begin{array}{l}\text { Area not affected by } \\
\text { eutrophication }\end{array}$ & - \\
\hline Good & $\begin{array}{l}\text { Slight change in } \\
\text { composition, biomass }\end{array}$ & $\begin{array}{l}\text { Non- } \\
\text { problem } \\
\text { area }\end{array}$ & $\begin{array}{l}\text { Area not affected by } \\
\text { eutrophication }\end{array}$ & $\begin{array}{l}\text { Human induced } \\
\text { eutrophication is } \\
\text { minimized }\end{array}$ \\
\hline Moderate & $\begin{array}{l}\text { Moderate change in } \\
\text { composition, biomass }\end{array}$ & $\begin{array}{l}\text { problem } \\
\text { area }\end{array}$ & $\begin{array}{l}\text { Area affected by } \\
\text { eutrophication }\end{array}$ & $\begin{array}{l}\text { Human induced } \\
\text { eutrophication is not } \\
\text { minimized }\end{array}$ \\
\hline Poor & $\begin{array}{l}\text { Major change in } \\
\text { biological communities }\end{array}$ & $\begin{array}{l}\text { problem } \\
\text { area }\end{array}$ & $\begin{array}{l}\text { Area affected by } \\
\text { eutrophication }\end{array}$ & $\begin{array}{l}\text { Human induced } \\
\text { eutrophication is not } \\
\text { minimized }\end{array}$ \\
\hline $\mathrm{Bad}$ & $\begin{array}{l}\text { Severe change in } \\
\text { biological communities }\end{array}$ & $\begin{array}{l}\text { problem } \\
\text { area }\end{array}$ & $\begin{array}{l}\text { Area affected by } \\
\text { eutrophication }\end{array}$ & $\begin{array}{l}\text { Human induced } \\
\text { eutrophication is not } \\
\text { minimized }\end{array}$ \\
\hline
\end{tabular}

Table 6 gives the assessment results of conventions and legislation instruments. Within this framework, the OSPAR and HELCOM assessments are similar with respect to the eutrophication criteria. While the MSFD focuses on human induced eutrophication, the WFD deals with the changing conditions of water bodies. TLI has seven; WFD, IFREMER and ASSETS have five; OSPAR, TRIX and CTSI have four; EPA and STI have three; and HEAT has two assessment categories, respectively. Although the indexes have different methods and variables, they aim to categorise trophic status according to their regional objectives. In that sense, the assessment types are matching with each other. Table 7 shows a general assessment of the widely used indexes and clearly indicates the trophic status equivalence between them. 
Table 7

Comparison of 11 Eutrophication Indexes According to Their Assessment Types of Trophic Status

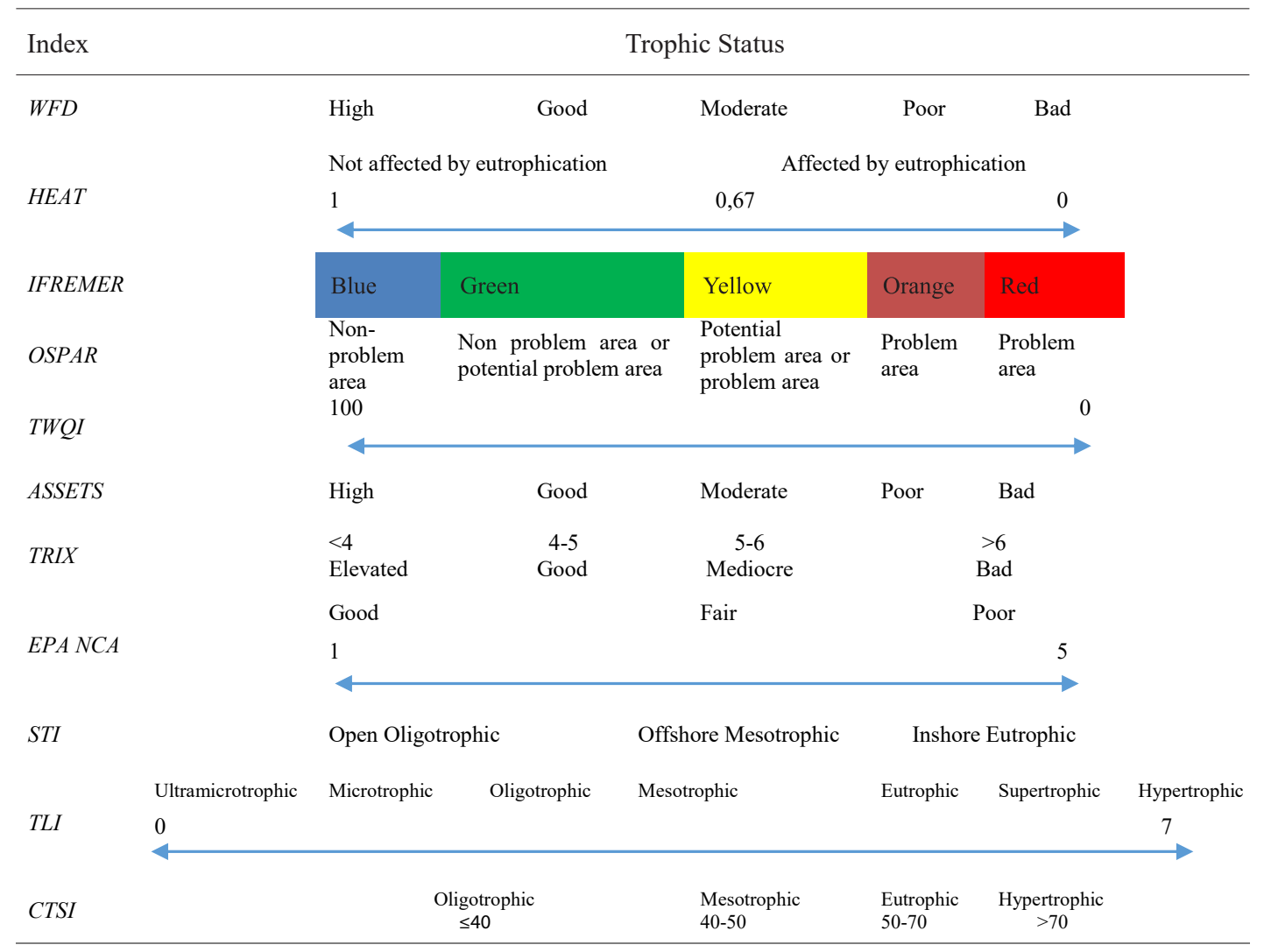

According to Table 7, trophic state equivalences of TRIX results of MEU (2018) in the other indexes could be read as Table 8 . 
Table 8

Trophic Status Equivalences of TRIX Results of MEU (2018) in the Other Indexes

\begin{tabular}{|c|c|c|c|c|}
\hline & \multicolumn{2}{|c|}{ Mediterranean } & \multicolumn{2}{|c|}{ Marmara } \\
\hline & Minnimum result & Maximum result & $\begin{array}{l}\text { Minnimum } \\
\text { result }\end{array}$ & Maximum result \\
\hline TRIX results & Less than 1 & More than 5 & Less than 3 & More than 6 \\
\hline \multicolumn{5}{|c|}{ Trophic status equivalences in the other indexes } \\
\hline WFD & High & Poor & High & $\mathrm{Bad}$ \\
\hline HEAT & $\begin{array}{l}\text { Not affected by } \\
\text { eutrophication }\end{array}$ & $\begin{array}{l}\text { Affacted by } \\
\text { eutrophication }\end{array}$ & $\begin{array}{l}\text { Not affected by } \\
\text { eutrophication }\end{array}$ & $\begin{array}{l}\text { Affacted by } \\
\text { eutrophication }\end{array}$ \\
\hline IFREMER & Blue & Yellow & Blue & Red \\
\hline OSPAR & Non-problem area & $\begin{array}{c}\text { Potential } \\
\text { problem area or } \\
\text { problem area }\end{array}$ & $\begin{array}{c}\text { Non-problem } \\
\text { area }\end{array}$ & Problem area \\
\hline TWQI & More than 84 & Less than 14 & More than 50 & Worst \\
\hline ASSETS & High & Moderate & High & Poor \\
\hline EPA NCA & Good & Fair & Good & Poor \\
\hline STI & Open oligitrophic & $\begin{array}{l}\text { Offshore } \\
\text { mesotrophic }\end{array}$ & $\begin{array}{c}\text { Open } \\
\text { olıgitrophic }\end{array}$ & Inshore eutrophic \\
\hline TLI & Ultramicrotrophic & Mesotrophic & Microtrophic & Supertrophic \\
\hline CTSI & Oligotrophic & Eutrophic & Oligotrophic & Eutrophic \\
\hline
\end{tabular}

By reviewing the indexes, researchers revealed that TRIX and HEAT have the same basic structures and provide rather harmonic results concerning the eutrophication status and trend (Stips et al., 2016). When TRIX and TWQI are compared one can see that data inputs are comparable with the exception of benthic flora and SD depth whose utilization is not obligatory in TWQI. IFREMER and TWQI show consistency except for waters having lower quality. IFREMER is restricted due to the limited variables whereas TWQI relies on integrated variables (Giordani et al., 2009 The new tool BEAST matches with the MSFD requirements in terms of water quality, and is much more correlated with the eutrophication parameters than TRIX as well as takes into account the influence of seawater temperature on eutrophication.

\section{Conclusion}

Eutrophication indexes are used for monitoring and quality assessment of water bodies. This study indicates that the classifications of the indexes are basically similar to each other, while their indicator parameters are different resulting from the inherent 
characteristics of the applied regions. In this context, there is not an internationally defined and accepted eutrophication index.

This paper is important to set forth a comprehensive search and categorizes commonly used eutrophication indexes in terms of their trophic status equivalence while indicating that there is no comparability between indexes as they are developed specific to region. 


\section{References}

Andersen, J. H., Axe, P., Backer, H., Carstensen, J., Claussen, U., Fleming-Lehtinen, \& V.,Korpinen, S. (2011). Getting the measure of eutrophication in the Baltic Sea: towards improved assessment principles and methods. Biogeochemistry, 106(2), 137-156.

Bonometto, A., Giordani, G., Ponis, G., Facca, C., Brusà, R. B., Sfriso, A., \& Viaroli, P. (2016. March). Eutrophication assessment in transitional waters A performance analysis of the Transitional Water Quality Index (TWQI). The VII Eurolag - European Coastal Lagoons Symposium. University of Murcia, Spain.

Borja, A., Basset, A., Bricker, S., Dauvin, J., Elliot, M., Harrison, T.,...West, R. (2012). Classifying ecological quality and integrity of estuaries. In E. Wolanski \& D. McLusky (Eds.), Treatise on Estuarine and Coastal Science (pp. 125-162). Waltham: Academic Press.

Bowie, G. L., Mills, W. B., Porcella, D. B., Campbell, C. L., Pagenkopf, J. R., Rupp, G. L., \& Chamberlin, C. E. (1985). Rates, constants, and kinetics formulations in surface water quality modeling (2nd ed., Vol. EPA/600/pp. 3-85/040). Athens, Georgia.

Bricker, S., Ferreira, J., \& Simas, T. (2003). An integrated methodology for assessment of estuarine trophic status. Ecological modelling, 169(1), 39-60.

U.S. Department of Commerce, National Oceanographic and Atmospheric Administration, National Ocean Service. (1999). National estuarine eutrophication assessment: effects of nutrient enrichment in the nation's estuaries. Silver Spring: National Ocean Service, National Oceanic and Atmospheric Administration.

BSC, HELCOM, \& EC. (2014). Environmental monitoring of the Black Sea with focus on nutrient pollution (Acronym: Baltic2Black). (Final Report for the Grant Agreement No 07.0204/2010/580913/ SUB/D2). Retrieved from https://ec.europa.eu/environment/marine/international -cooperation/ regional-sea-conventions/bucharest/pdf/Baltic2Black\%20report.pdf

Burns, N., Bryers, G., \& Browman, E. (2000). Protocol for monitoring trophic levels of New Zealand lakes and reservoirs. New Zealand: Ministry for the Environment.

Burns, N. M., Rutherford, J. C., \& Clayton, J. S. (1999). A monitoring and classification system for New Zealand lakes and reservoirs. Lake and Reservoir Management, 15(4), 255-271.

Canfield Jr, D. E., \& Bachmann, R. W. (1981). Prediction of total phosphorus concentrations, chlorophyll a, and Secchi depths in natural and artificial lakes. Canadian Journal of Fisheries and Aquatic Sciences, 38(4), 414-423.

Carlson, R. E. (1977). A trophic state index for lakes1. Limnology and oceanography, 22(2), 361-369.

Carlson, R. E., \& Simpson, J. (1996). A coordinator's guide to volunteer lake monitoring methods. North American Lake Management Society, 96, 305. 
Chapra, S. C. (1977). Total phosphorus model for the Great Lakes. Journal of the Environmental Engineering Division, 103(2), 147-161.

Cloern, J. E. (2001). Our evolving conceptual model of the coastal eutrophication problem. Marine ecology progress series, 210, 223-253.

Conley, D. J., Kaas, H., Møhlenberg, F., Rasmussen, B., \& Windolf, J. (2000). Characteristics of Danish estuaries. Estuaries, 23(6), 820-837.

Cunha, D. G. F., do Carmo Calijuri, M., \& Lamparelli, M. C. (2013). A trophic state index for tropical/ subtropical reservoirs (TSItsr). Ecological Engineering, 60, 126-134.

Devlin, M., Bricker, S., \& Painting, S. (2011). Comparison of five methods for assessing impacts of nutrient enrichment using estuarine case studies. Biogeochemistry, 106(2), 177-205.

Dillon, P. J., \& Rigler, F. (1974). The phosphorus-chlorophyll relationship in lakes 1, 2. Limnology and Oceanography, 19(5), 767-773.

Dodds, W. K. (2002). Freshwater ecology: concepts and environmental applications. California, USA: Academic Press, Elsevier.

European Commission. (2010). 2010/477/EU Commission decision of 1 September 2010 on criteria and methodological standards on good environmental status of marine waters $(\mathrm{C}(2010) 5956)$. Official Journal of the European Union, L, 232, 14-24.

European Commission WFD Guidance. (2003). Common Implementation Strategy for the Water Framework Directive (2000/60/EC), Guidance Document No5. Transitional and Coastal Waters Typology, Reference Conditions and Classification Systems.

European Commission WFD Technical Report. (2009). Common Implementation Strategy for the Water Framework Directive (2000/60/EC), (Guidance Document No. 23). Guidance Document on Eutrophication Assessment in the Context of European Water Policies.

European Communities. (2000). Council directive 2000/60/EC of the European Parliament and of the Council of 23 October 2000 establishing a framework for community action in the field of water policy. Official Journal of European Communities, 50(327), 1-72.

European Union. (2008). Directive 2008/56/EC of The European Parliament and of the Council of 17 June 2008 Establishing a Framework for Community Action in the Field of Marine Environmental Policy (Marine Strategy Framework Directive MSFD). Official Journal of the European Union, 19-40.

Ferreira, J. G., Andersen, J. H., Borja, A., Bricker, S. B., Camp, J., Da Silva, M. C., \& Ignatiades, L. (2011). Overview of eutrophication indicators to assess environmental status within the European Marine Strategy Framework Directive. Estuarine, Coastal and Shelf Science, 93(2), 117-131. 
Galloway, J. N., \& Cowling, E. B. (2002). Reactive nitrogen and the world: 200 years of change. AMBIO: A Journal of the Human Environment, 31(2), 64-71.

Giordani, G., Zaldívar, J. M., \& Viaroli, P. (2009). Simple tools for assessing water quality and trophic status in transitional water ecosystems. Ecological Indicators, 9(5), 982-991.

Giovanardi, F., \& Vollenweider, R. A. (2004). Trophic conditions of marine coastal waters: experience in applying the Trophic Index TRIX to two areas of the Adriatic and Tyrrhenian seas. Journal of Limnology, 63(2), 199-218.

Glibert, P. M., Harrison, J., Heil, C., \& Seitzinger, S. (2006). Escalating worldwide use of urea-a global change contributing to coastal eutrophication. Biogeochemistry, 77(3), 441-463.

Heiskary, S. A., \& Bouchard Jr, R. W. (2015). Development of eutrophication criteria for Minnesota streams and rivers using multiple lines of evidence. Freshwater Science, 34(2), 574-592.

HELCOM. (2007). HELCOM Baltic Sea Action Plan. Krakow, Poland.

HELCOM. (2009). Eutrophication in the Baltic Sea - An integrated thematic assessment of the effects of nutrient enrichment and eutrophication in the Baltic Sea region (Balt. Sea Environ. Proc. No. 115B). Helsinki Commision, Finland.

Howarth, R. W., Sharpley, A., \& Walker, D. (2002). Sources of nutrient pollution to coastal waters in the United States: Implications for achieving coastal water quality goals. Estuaries, 25(4), 656676.

Hoyer, M. V., Terrell, J. B., \& Canfield Jr, D. E. (2015). Chain of eutrophication models for assessing the potential impact of nutrient enrichment on Choctawhatchee Bay, FL, USA. Florida Scientist, 20-36.

Ignatiades, L. (2005). Scaling the trophic status of the Aegean Sea, eastern Mediterranean. Journal of Sea Research, 54(1), 51-57.

Jiang, P., Cui, Y., Wang, H., \& Wang, H. (2011). Macrobenthos communities and bio-assessment of lakes in Hanyang district. Resources and Environment in the Yangtze Basin, 20(5), 525-533.

Jones, J. R., \& Bachmann, R. W. (1976). Prediction of phosphorus and chlorophyll levels in lakes. Journal (Water Pollution Control Federation), 2176-2182.

Kitsiou, D., \& Karydis, M. (2011). Coastal marine eutrophication assessment: a review on data analysis. Environment international, 37(4), 778-801.

Kupchella, C. E., \& Hyland, M. C. (2nd ed.). (1989). Environmental Science: Living within the system of nature. Boston: Allyn and Bacon. 
Lazar, L., Boicenco, L., Beken, C., Dzhurova, B., Moncheva, S., Shtereva, G., \& Vasiliu, D. (2016). Western black sea eutrophication status according to the black sea eutrophication asessment tool, BEAST-MISIS cruise results. Cercet. Mar., 46, 48-60.

Liebig, J. v. (1840). Organic chemistry in its application to vegetable physiology and agriculture. Readings in ecology. New York, NY: Prentice Hall.

MEU, (2018). Marine quality bulletin. Retrieved from https://ced.csb.gov.tr/deniz-kalitesibulteni-i-84199

Nielsen, S. L., Sand-Jensen, K., Borum, J., \& Geertz-Hansen, O. (2002). Phytoplankton, nutrients, and transparency in Danish coastal waters. Estuaries, 25(5), 930-937.

OSPAR. (2008). Marine biodiversity monitoring and assessment: Activities to improve synergies between EU directives and international conventions, Activities in all OSPAR Contracting Parties: OSPAR Commission.

OSPAR. (2017). Eutrophication Status of the OSPAR Maritime Area, Third Integrated Report on the Eutrophication Status of the OSPAR Maritime Area. Eutrophication Series. Retrieved from www. ospar.org

Pan, B.-Z., Wang, H.-Z., Pusch, M. T., \& Wang, H.-J. (2015). Macroinvertebrate responses to regime shifts caused by eutrophication in subtropical shallow lakes. Freshwater Science, 34(3), 942-952.

Parparov, A., Gal, G., Hamilton, D. P., Kasprzak, P., \& Ostapenia, A. (2010). Water quality assessment, trophic classification and water resources management. Journal of Water Resources Protection, 2, 907-915

Pettine, M., Casentini, B., Fazi, S., Giovanardi, F., \& Pagnotta, R. (2007). A revisitation of TRIX for trophic status assessment in the light of the European Water Framework Directive: Application to Italian coastal waters. Marine Pollution Bulletin, 54(9), 1413-1426.

Rask, N., Pedersen, S. E., \& Jensen, M. H. (1999). Response to lowered nutrient discharges in the coastal waters around the island of Funen, Denmark. In Biological, Physical and Geochemical Features of Enclosed and Semi-enclosed Marine Systems (pp. 69-81): Springer.

Rinaldi, A., \& Giovanardi, F. (2011). Contribution of Richard A. Vollenweider toward understanding eutrophication of the coastal Adriatic Sea. Aquatic Ecosystem Health \& Management, 14(2), 200203.

Smil, V. (2004). Enriching the earth: Fritz Haber, Carl Bosch, and the transformation of world food production. London, England: The MIT Press.

Souchu, P., Ximenes, M., Lauret, M., Vaquer, A., \& Dutrieux, E. (2000). Mise à jour d'indicateurs du niveau d'eutrophisation des milieux lagunaires méditerranéens, août 2000. Ifremer-CréoceanUniversité Montpellier II, 412. 
Stips, A., Macias, D., Garcia-Gorriz, E., \& Miladinova, S. (2016). Alternative assessments of large scale Eutrophication using ecosystem simulations: Hind-casting and scenario modelling. Luxembourg (Luxembourg) EUR, 27904.

Tas, S., \& Y1lmaz, I.E. (2015). Potentially harmful microalgae and algal blooms in a eutrophic estuary in the Sea of Marmara (Turkey). Mediterranean Marine Science, 16(2), 432-443.

Tsakiris, G. (2015). The status of the European waters in 2015: a review. Environmental Processes, 2(3), 543-557.

Turkoglu, M. (2013). Red tides of the dinoflagellate Noctiluca scintillans associated with eutrophication in the Sea of Marmara (the Çanakkale Strait, Turkey). Oceanologia, 55(3), 709-732.

UNEP/MAP. (2007a). Approaches to the Assessment of Eutrophication in Mediterranean Coastal Waters (UNEP(DEPI)/MED WG.321/Inf.6). Athens: UNEP/MAP.

UNEP/MAP. (2007b). Eutrophication Monitoring Strategy for the MED POL (UNEP(DEPI)/MED WG.321/Inf.5). Athens: UNEP/MAP.

USEPA. (2004). National Coastal Condition Report II (EPA-620/R-03/002). Washington, DC: Office of Research and Development. Retrived from: https:/www.epa.gov/sites/production/files/2014-10/ documents/nccriicomplete.pdf

USEPA. (2008). EPA's 2008 Report on the Environment (EPA/600/R-07/045F). Washington, DC: National Center for Environmental Assessment.. Available from the National Technical Information Service, Springfield, VA,Retrived from: http://www.epa.gov/roe.:

Vollenweider, R., Giovanardi, F., Montanari, G., \& Rinaldi, A. (1998). Characterization of the trophic conditions of marine coastal waters with special reference to the NW Adriatic Sea: proposal for a trophic scale, turbidity and generalized water quality index. Environmetrics, 9(3), 329-357.

Vollenweider, R., \& Kerekes, J. (1980). Loading concept as basis for controlling eutrophication philosophy and preliminary results of the OECD Programme on Eutrophication. Progress in Water Technology, 12, 5-38.

Vollenweider, R., Marchetti, R., \& Viviani, R. (1992). Marine coastal eutrophication. The response of marine transitional systems to human impacts: problems and perspectives for restoration. Science of the Total Environment Supplement. Amsterdam, Netherlands: Elsevier Science.

Vollenweider, R. A. (1976). Advances in defining critical loading levels for phosphorus in lake eutrophication. Memorie dell'Istituto Italiano di Idrobiologia, Dott. Marco de Marchi Verbania Pallanza, 33, 53-83.

Zaldívar, J.-M., Viaroli, P., Newton, A., De Wit, R., Ibañez, C., Reizopoulou, S., Holmer, M. (2008). Eutrophication in transitional waters: an overview. Transitional Waters Monographs, 2(1), 1-78. 


\section{Extended Turkish Abstract (Genişletilmiş Türkçe Özet)}

\section{Yaygın Olarak Kullanılan Ötrofikasyon İndekslerinin Karşılaştırılması ve Değerlendirilmesi}

Ötrofikasyon sucul ortamdaki besi maddesi artışına bağlı olarak su kütlesindeki canlı ve cansız çevre üzerinde olumsuz etkilere, su kalitesinde bozulmalara yol açan bir olgudur. Sucul ortamlarda trofik durumun oligotrofikten ötrofik duruma doğru gitmesi ortamdaki besi maddesi artışının bir göstergesidir. Ötrofikasyon indeksleri, trofik durumu sınıflandırmaya yarayan bir araç olarak kullanılmaktadır. Ayrıca sucul ortamın sürdürülebilirliği açısından trofik durumun izlenmesine, sınıflandırılmasına ve iyileştirilmesine bölgesel ve uluslararası sözleşmelerde sıklıkla değinilmektedir. $\mathrm{Bu}$ nedenle geçmişten günümüze, trofik durumu belirlemede birçok çalışma yapılmış; birçok yaklaşım ortaya konmuştur.

Ötrofikasyon indeksleri bölgelere özgü olarak geliştirilmiştir. Her bir bölgenin koşulları birbirinden farklı olduğu için bir bölgeye özgü geliştirilen indeks, başka bir bölgede gerçekçi sonuçlar vermeyebilir. Bu kapsamda, kullanılacak parametreler birbirinden farklılık gösterebilmektedir. Bununla birlikte, bazı indekslerin su kalitesinin iyi olduğu bölgelerde birbiriyle uyumlu sonuçlar verdiği görülmektedir. Ancak trofik durum kötüleştikçe, bu sonuçların birbirleriyle tutarlılığının azaldığı görülmektedir. Bu nedenle, bölgeye özgü indeks seçimi önem arz etmektedir.

Su Çerçeve Direktifi (WFD) ve ABD Çevre Koruma Ajansı (USEPA) gibi uluslararası kuruluşların mevzuatlarında, farklı su kütleleri için uygulanabilecek değerlendirme araçlarının geliştirilmesi önerilmektedir. Bu nedenle, ötrofikasyonu yönetmek için birbiriyle ilişkili değişkenlerden gelen bilgileri analiz etmek ve değerlendirmek amacıyla entegre yaklaşımlar büyük öneme sahiptir. Bununla birlikte uluslararası geçerliliği olan ve her bölge için kullanılabilecek standart bir ötrofikasyon indeksi yoktur. Ötrofikasyon indeksleri, bölgesel gereklilikler doğrultusunda, bir bölgeyi temsil eden belirli durum değişkenleri ve parametrelerden oluşan veri setleri kullanılarak geliştirilmiştir. $\mathrm{Bu}$ nedenle, indeks sonuçlarının kıyaslanması mümkün değildir.

Bu çalışmada, yaygın olarak kullanılan 11 farklı ötrofikasyon indeksi, her bir indeksin uygulandığ 1 bölgeler, kullanılan parametreler ve trofik durum sınıflandırmaları açısından değerlendirilmiştir. Bu çalışma ile araştırmacılara, bir su kütlesinin trofik durumunu değerlendirirken ötrofikasyon indeksleri ile ilgili kapsamlı ve karşılaştırılmalı bir yaklaşım sunmak hedeflenmiştir. Bu değerlendirme kapsamında klorofil-a temel biyolojik parametre olarak tüm indekslerde görülmektedir. Fiziko-kimyasal parametreler içerisinde ise çözünmüş oksijen göstergesinin tüm indekslerde kullanıldığı görülmektedir. Bu parametrelerin doğrudan ötrofikasyon ile ilgilidir. Bununla birlikte; çözünmüş oksijen, çözünmüş inorganik azot, çözünmüş inorganik fosfor, toplam azot, toplam fosfor, seki derinliği, bitkisel yayılım gibi parametreler indekslerin alan koşullarına göre hesaplama kriterleri içerisinde yer almaktadır.

Aşağıda verilen tablo indekslerin trofik durum sınıflandırma türlerini göstermektedir. $\mathrm{Bu}$ kapsamda sırasıyla TLI yedi; WFD, IFREMER ve ASSETS beş; OSPAR, TRIX ve CTSI dört; EPA ve STI üç; HEAT iki kategoride trofik durum sonuçlarını sunmaktadır. İndeksler farklı metot ve parametreler kullansalar da, indekslerin trofik durum değerlendirme şekilleri temelde birbiriyle örtüşmektedir. Bu çalışmada, indekslerin trofik durum eşdeğerleri ortaya konmuştur. 
Ötrofikasyon indeksleri incelendiğinde USEPA ve WFD yöntemindeki değerlendirme tiplerinin temel bir yaklaşım olduğu görülmektedir. USEPA yöntemi, ABD sularındaki uygulamaları kapsamakta; WFD ise Avrupa Birliği ve aday ülke su kaynaklarına ulaşan her türlü baskıyı dikkate almaktadır. WFD su kütlelerinin değişen durumları üzerinde durmaktadır. WFD, HELCOM, OSPAR ve MSFD gibi uluslararası mevzuatlarına bakıldığında, WFD'nin ötrofik durum sınıflandırmasının daha detaylı olduğu görülürken diğer mevzuatlar iki kategoride sınıflandırma ile sınırlıdır. WFD'nin alt direktifi olan MSFD'de antropojenik kökenli ötrofikasyona dikkat çekildiği görülmektedir.

\section{Tablo}

Trofik Durum Değerlendirme Özelliklerine Göre Ötrofikasyon Indekslerinin Karşılaştırılması

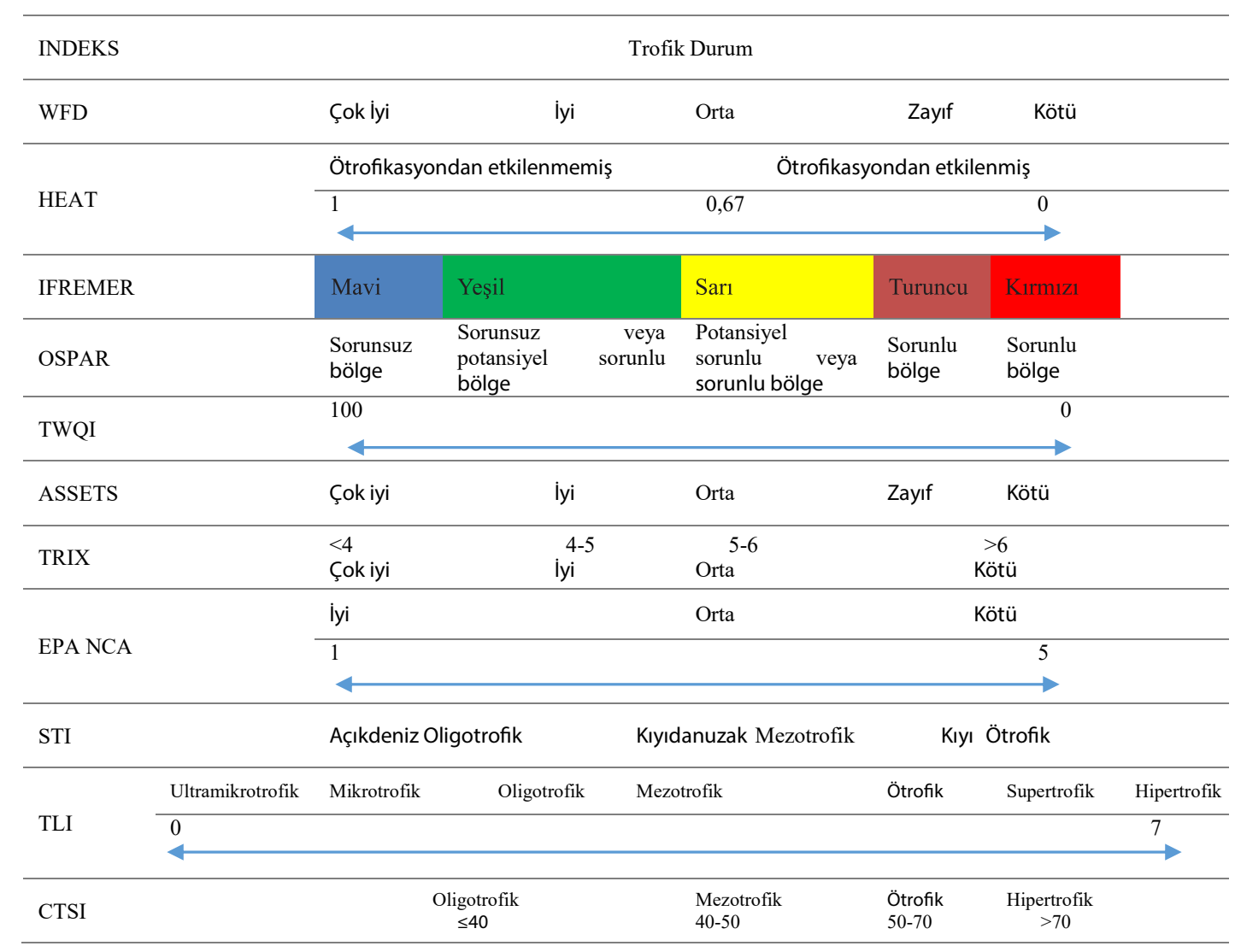


HEAT ve OSPAR indeksleri özellikle besin zenginliği ve çoğalma durumlarının etkilerini dikkate almaktadır. OSPAR ve HELCOM ötrofikasyon değerlendirmelerinin benzer olduğu görülmektedir. WFD ve HEAT tarafından önerilen şekilde, HEAT indeksinde bir EQR'yi hesaplamak için, son izleme verilerinden sapma ve tipe özgü referans koşul durumları karşılaştırılmaktadır. Sonuçlar, ekolojik durum açısından değerlendirilerek en kötü sonuca sahip parametre üzerinden belirlenir. WFD'nin “One-out all-out” prensibine göre, izleme sonuçlarından bir parametre dahi kötü ise o bölgenin nihai su kalitesi sınıfı o parametrenin sonucuna göre değerlendirilir. OSPAR, kriterlerin her biri için bölgeye özgü ve/veya geçmiş referans verilerini kullanır. Bu yöntemde besin maddelerinin yalnızca kış dönemindeki izleme sonuçlarının kullanılması ve yöntemin açık denizlerde kullanılması, OSPAR'a akit olmayan taraflarca indeksin test edilmesini zorlaştıracağı düşünülmektedir.

Detaylı literatür analizinden anlaşıldığı üzere araştırmacılar, TRIX ve HEAT'in aynı temel yapılara sahip olduğunu ve ötrofikasyon durumu/eğilimi ile ilgili oldukça uyumlu bir sonuç çıkardığını ortaya koymuşlardır. TRIX ve TWQI indekslerine bakıldığında ise, veri girişlerinin TWQI'de belirtilen bentik flora ve aynı zamanda TRIX'te kullanımı zorunlu olmayan seki diski derinliği parametresi haricindeki benzerlikleriyle karşılaştıılabilir oldukları görülebilir. IFREMER ve TWQI sonuçları, daha düşük kaliteye sahip bölgeler dışında tutarlılık göstermektedir. IFREMER sınırlı değişkenlere sahip iken, TWQI bütünleşik değişkenlere dayanır. Diğer taraftan, BEAST yaklaşımı su kalitesi değerlendirme prensibi açısından MSFD gereklilikleriyle eşleşmektedir. BEAST yaklaşımının TRIX'e göre daha fazla ötrofikasyon parametresi ile eşleşmekte olduğu ve aynı zamanda deniz suyu sıcaklığının ötrofikasyon üzerindeki etkisini de dikkate aldığı görülmektedir. 